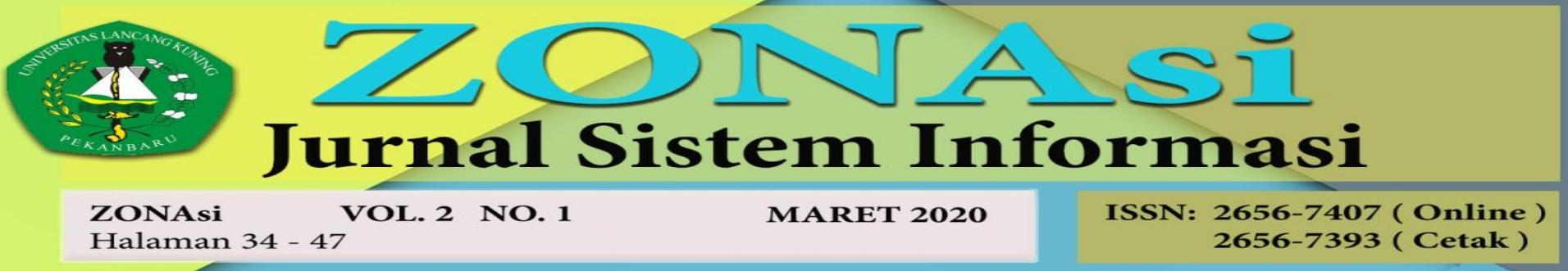

\title{
IMPLEMENTASI METODE WATERFALL DALAM MEMBANGUN SISTEM INFORMASI SEKOLAH DI SMK.S AL HABIBATAIN BUMIAYU
}

\author{
Mukrodin \\ (Program Studi Sistem Informasi Universitas Peradaban)
}

(Jl. Raya Pagojengan Km 3 Bumiayu Brebes 52276, tlp. 0289-3420032, fax. 0289-430003)

e-mail: mukrodins@gmail.com

\begin{abstract}
Abstrak
SMK.S Al Habibatain Bumiayu yang berlokasi di Brebes pada saat ini telah ada dua program studi diantaranya yaitu Jurusan Teknik Komputer Jaringan dan Teknik Sepeda Motor, dalam pelaksanaan di saat ini aktifitas yang dilakukan di sekolah masih menggunakan pelayanan menggunakan sistam konvensional bahkan sekolah tersebut belum memiliki website termasuk dalam pendafataran mahasiswa baru dan penelusuran alumni. Hal tersebut berdampak pada pelayanan menjadi melambat dan sulit untuk menelusuri para alumni yang sudah bekerja ataupun yang sedang kuliah. Dari persoalan yang ada maka penulis berinisiatif melakukan penelitian untuk mengembangkan sistem informasi sekolah dengan menerapkan metode waterfall untuk meningkatkan pelayanan yang selama ini masih terkendala. Metode waterfall adalah metode yang bersifat sistematis dan berurutan dalam membangun sebuah aplikasi, waterfall juga sering disebut dengan classical life cycle. Sehingga metode waterfall sangat cocok dalam membangun aplikasi yang baru dan juga dalam pengembangan aplikasi dengan tingkat resiko yang kecil serta waktu pengembangan yang relative cukup cepat.
\end{abstract}

Kata kunci: waterfall, sekolah menengah kejuruan, sistem informasi akademik

\begin{abstract}
Al Habibatain Bumiayu Vocational School Brebes has two study programs namely the Department of Network Computer Engineering and Motorcycle Engineering, so far the activities carried out at the school still use manual services even the school does not yet have a website including the registration of new students and alumni tracking. This makes the service slow and difficult to track alumni who are already working or who are in college. From the existing problems, the authors took the initiative to conduct research to develop school information systems by applying the waterfall method to improve services that are still constrained. Waterfall method is a method that is systematic and sequential in building an application, the waterfall is also often called the classical life cycle. So that the waterfall method is very suitable in building new applications and also in application development with a small risk level and relatively fast development time.
\end{abstract}

Keywords: waterfall, vocational high school, academic information system 


\section{Pendahuluan}

Perkembangan aplikasi website / aplikasi internet secara umum semakin pesat sejak munculnya teknologi internet sangat membantu dalam kemudahan serta kecepatan pengiriman, penyampaian dan penerimaan informasi. Mulai dari perusahaan, sekolah, perguruan tinggi, dan lembaga atau organisasi lainnya telah banyak memanfaatkan aplikasi website dalam kegiatan penjualan, promosi, belajar dan kegiatan lainnya dimana dibutuhkan pengiriman, penyebaran dan penerimaan informasi sehingga memberikan kemudahan bagi pengguna (user) yang membutuhkan.

Aplikasi web atau bisa disebut juga dengan perangkat lunak berbasis website telah berkembang dengan pesat baik dari segi penggunaan, ukuran, bahasa yang digunakan dan kompleksitasnya. Aplikasi website pada mulanya hanya berupa situs web yang bersifat statis, serta lebih banyak digunakan sebagai brosur produk atau profil perusahaan online. Pada saat ini aplikasi website telah banyak yang bersifat dinamis, interaktif dan task oriented untuk digunakan dalam sistem informasi, telekomunikasi, perdagangan, perbankan dan lain-lain.

SMK.S Al Habibatain Bumiayu Kabupaten Brebes Jawa Tengah, selama ini belum memiliki sistem informasi maupun website sekolah sendiri yang dapat diakses dengan mudah oleh masyarakat umum dan warga sekolah terutama berkaitan dengan pendaftaran siswa baru, serta pelacakan lulusan yang ada. Sehingga informasi mengenai beberapa program yang berada di SMK tersebut masih sangat kurang. Dari permasalahan yang ada, maka penulis membuat sebuah sistem informasi akademik yang bisa melakukan pelacakan alumni, pendaftaran siswa baru secara online dengan menggunakan metode waterfall dalam pengembangannya. Dengan harapan dengana pembangunan sistem informasi akademik ini dapat membantu masyarakat dan warga sekolah mengakses informasi mengenai SMK.S Al Habibatain Bumiayu dengan cepat, mudah, dan efisien, dan dapat dilakukan di manapun.

\section{Metode Penelitian}

\subsection{Metode Pengembangan Sistem}

Metode penelitian yang diterapkan pada penelitian ini adalah dengan pengembangan metode waterfall. Metode waterfall merupakan model pengembangan sistem informasi yang terstruktur dan berurutan.

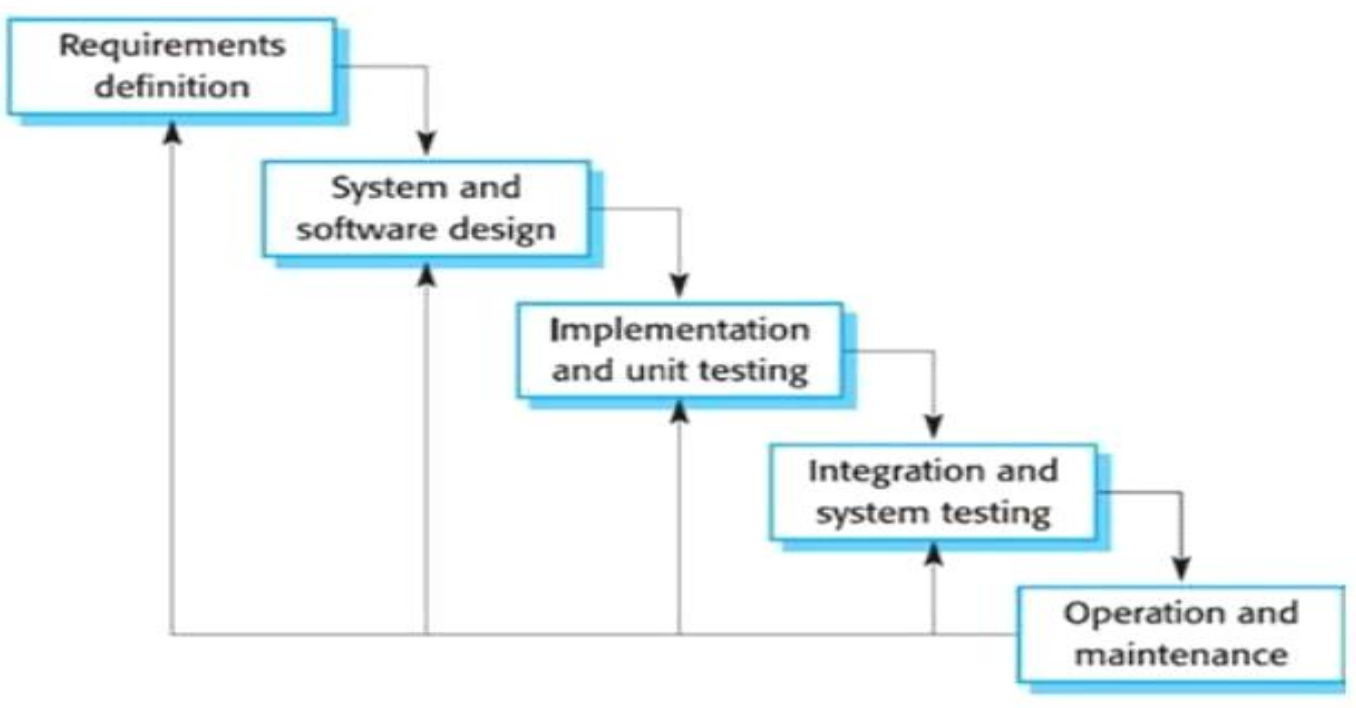

Gambar 1. Bagan metode waterfall 
Metode Waterfall memiliki tahapan-tahapan sebagai berikut:

1. Requirements analysis and definition

Layanan sistem, kendala, dan tujuan ditetapkan oleh hasil konsultasi dengan pengguna yang kemudian didefinisikan secara rinci dan berfungsi sebagai spesifikasi sistem.

2. System and software design

Tahapan perancangan sistem mengalokasikan kebutuhan-kebutuhan sistem baik perangkat keras maupun perangkat lunak dengan membentuk arsitektur sistem secara keseluruhan. Perancangan perangkat lunak melibatkan identifikasi dan penggambaran abstraksi sistem dasar perangkat lunak dan hubungannya.

3. Implementation and unit testing

Pada tahap ini, perancangan perangkat lunak direalisasikan sebagai serangkaian program atau unit program. Pengujian melibatkan verifikasi bahwa setiap unit memenuhi spesifikasinya.

4. Integration and system testing

Unit-unit individu program atau program digabung dan diuji sebagai sebuah sistem lengkap untuk memastikan apakah sesuai dengan kebutuhan perangkat lunak atau tidak. Setelah pengujian, perangkat lunak dapat dikirimkan ke customer

5. Operation and maintenance

Biasanya (walaupun tidak selalu), tahapan ini merupakan tahapan yang paling panjang. Sistem dipasang dan digunakan secara nyata. Maintenance melibatkan pembetulan kesalahan yang tidak ditemukan pada tahapan-tahapan sebelumnya, meningkatkan implementasi dari unit sistem, dan meningkatkan layanan sistem sebagai kebutuhan baru.

\subsection{Perancangan Sistem}

\subsubsection{Unified Modeling Language (UML)}

2.2.2.1 Entity Relationship Diagram (ERD)

Berikut ini merupakan perancangan ERD dari website sekolah SMK.S Al Habibatain Bumiayu digambarkan sebagai berikut:

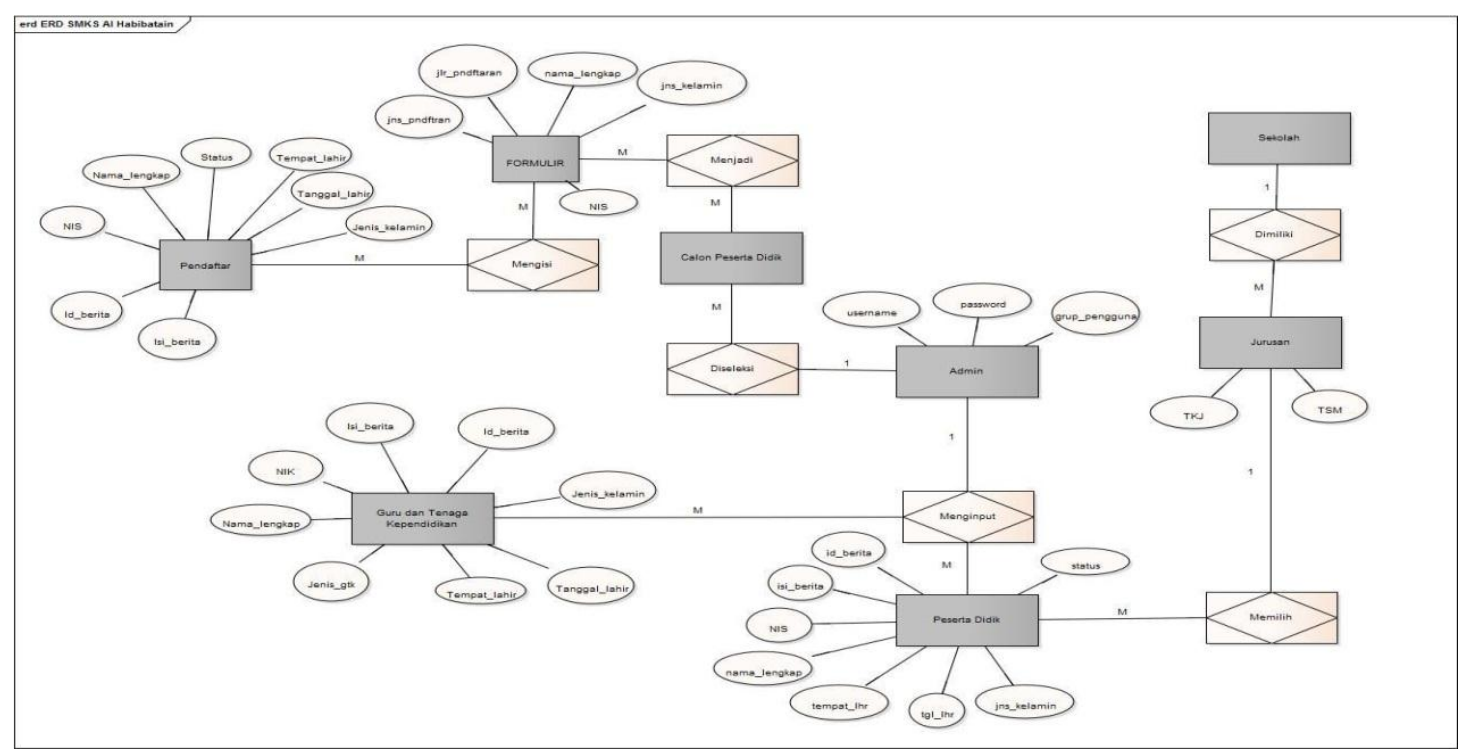

Gambar 2. Entity Relationship Diagram (ERD)

\subsubsection{Use Case Diagram} berikut :

Diagram use case dari website sekolah SMK.S Al Habibatain Bumiayu adalah sebagai 


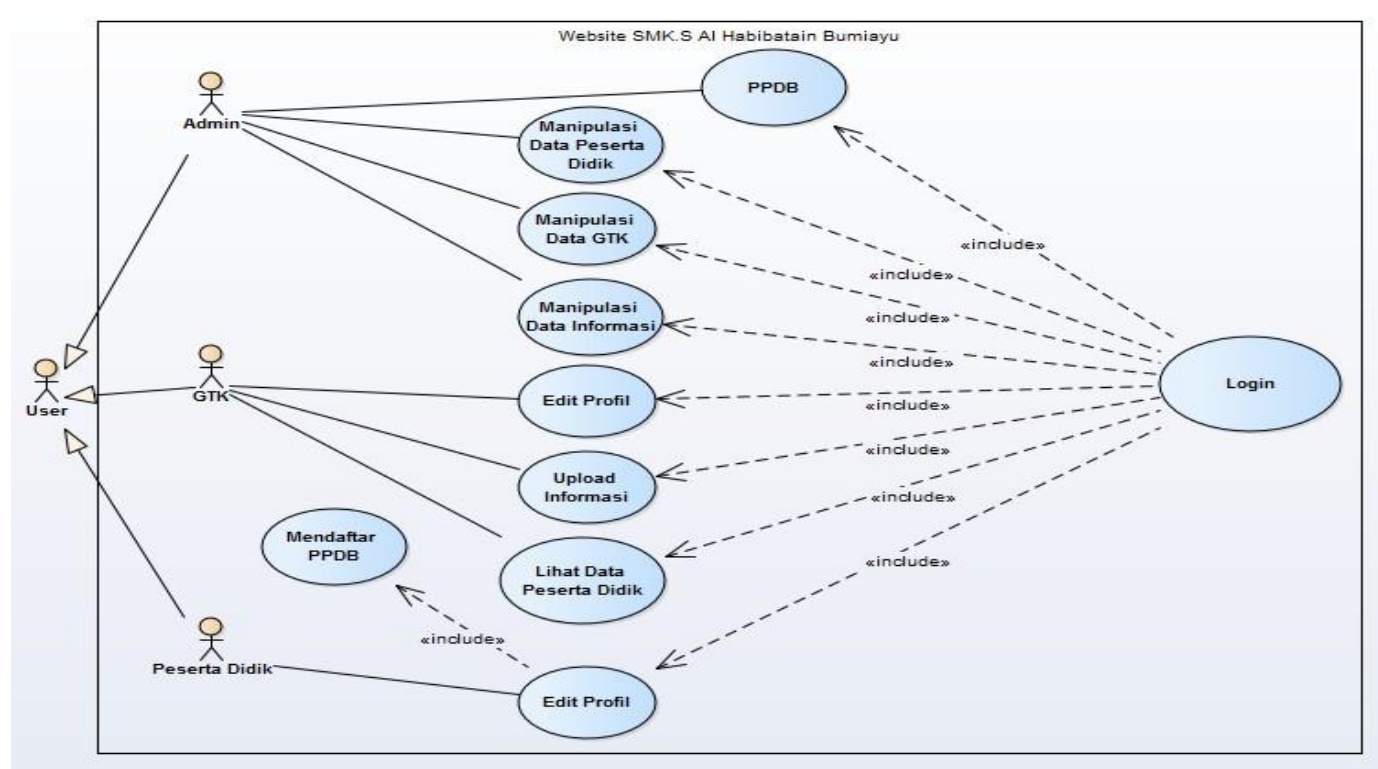

Gambar 3. Use Case Diagram Website SMK.S Al Habibatain Bumiayu

\subsubsection{Activity Diagram Use Case Login}

Activity Diagram adalah salah satu cara untukmemodelkan event-event yang terjadi dalam suatu Use Case. Activity Diagram berikut menggambarkan proses Login admin terhadap isi web sebagai berikut:

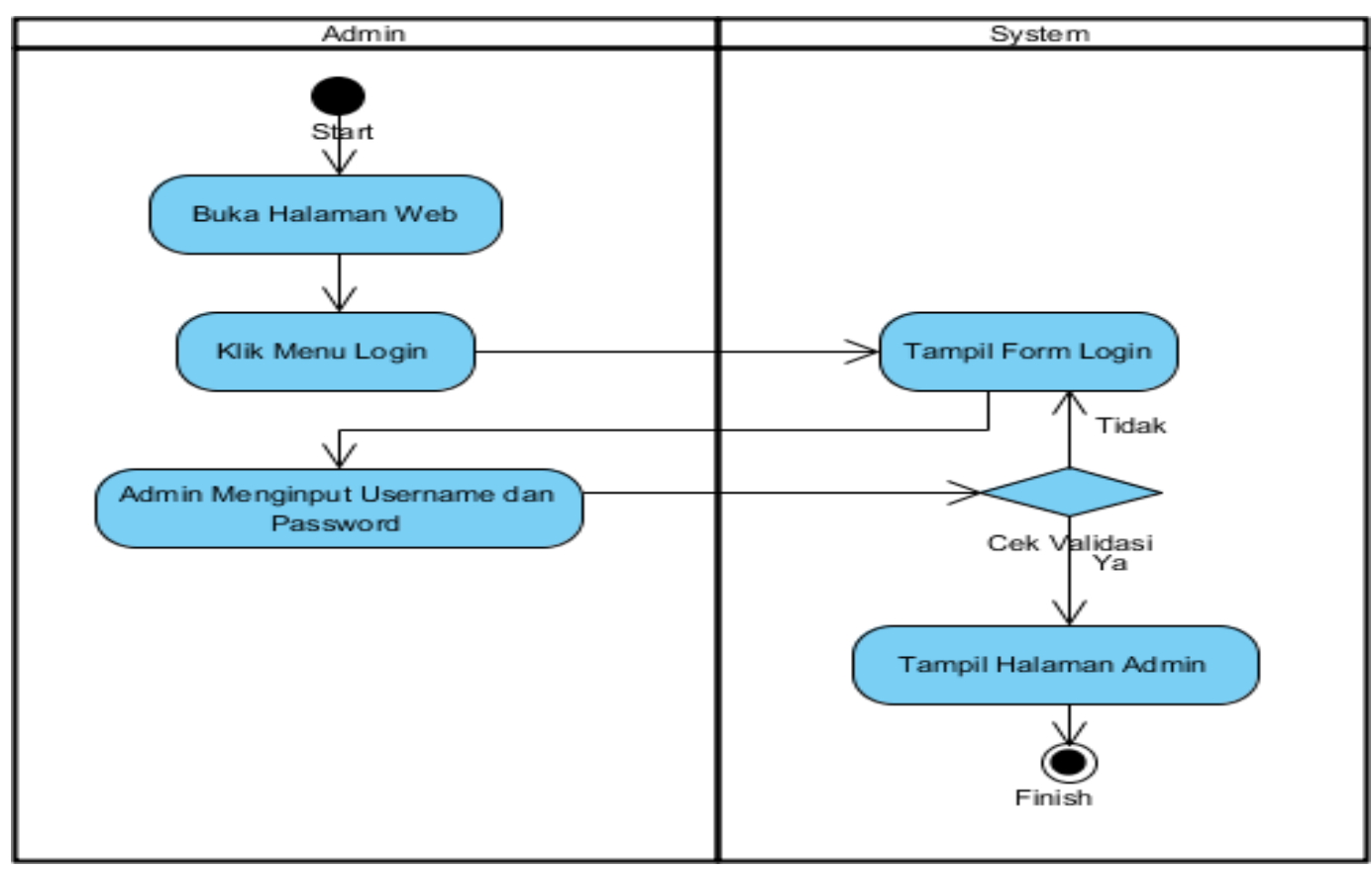

Gambar 4. Activity Diagram Use Case Login

\subsubsection{Activity Diagram Use Case Aktivasi Akun DataAlumni}


Activity Diagram berikut menggambarkan proses aktivasi akun data alumni terhadap isi web sebagai berikut :

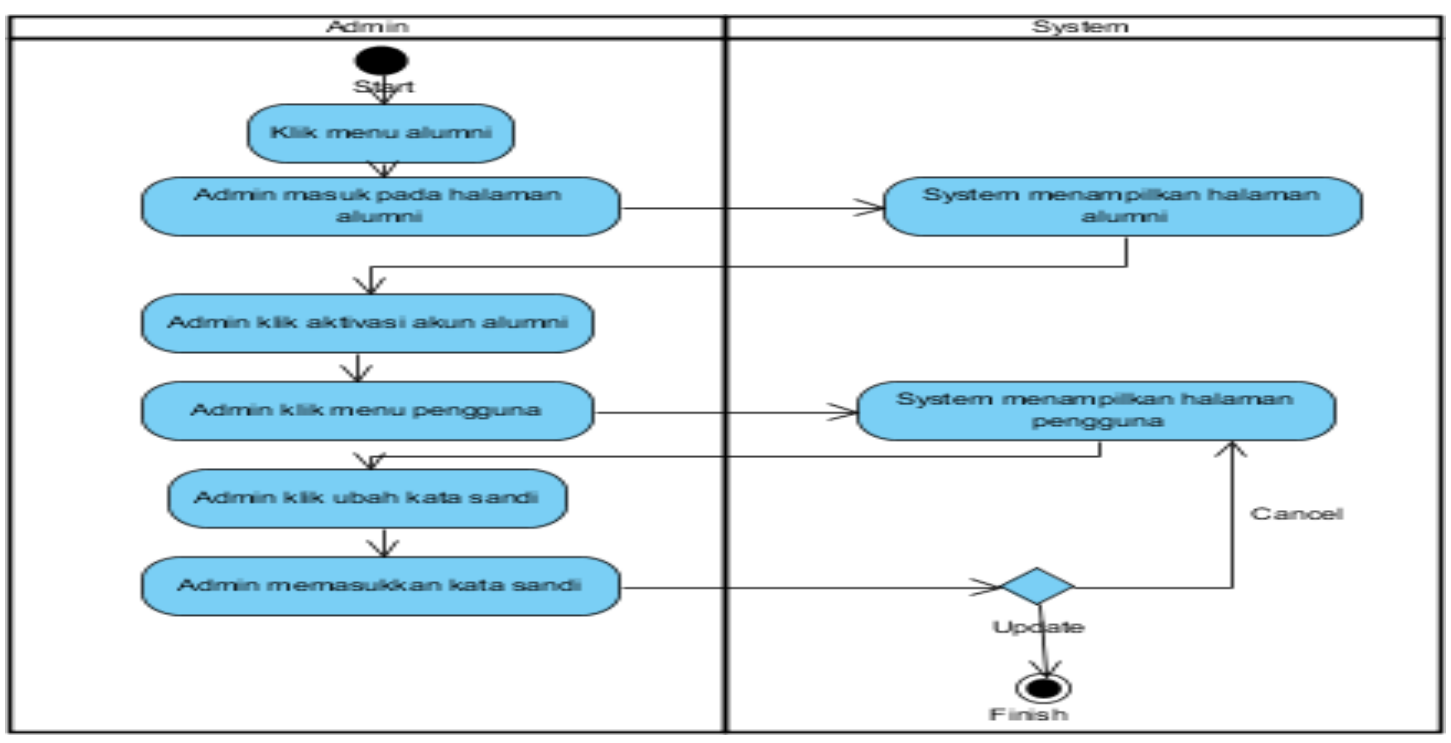

Gambar 5. Activity Diagram Use Case Aktivasi Akun Data Alumni

\subsubsection{Activity Diagram Use Case Menambah Data Calon Peserta didik}

Activity Diagram berikut menggambarkan proses menambah data calon peserta didik terhadap isi web sebagai berikut :

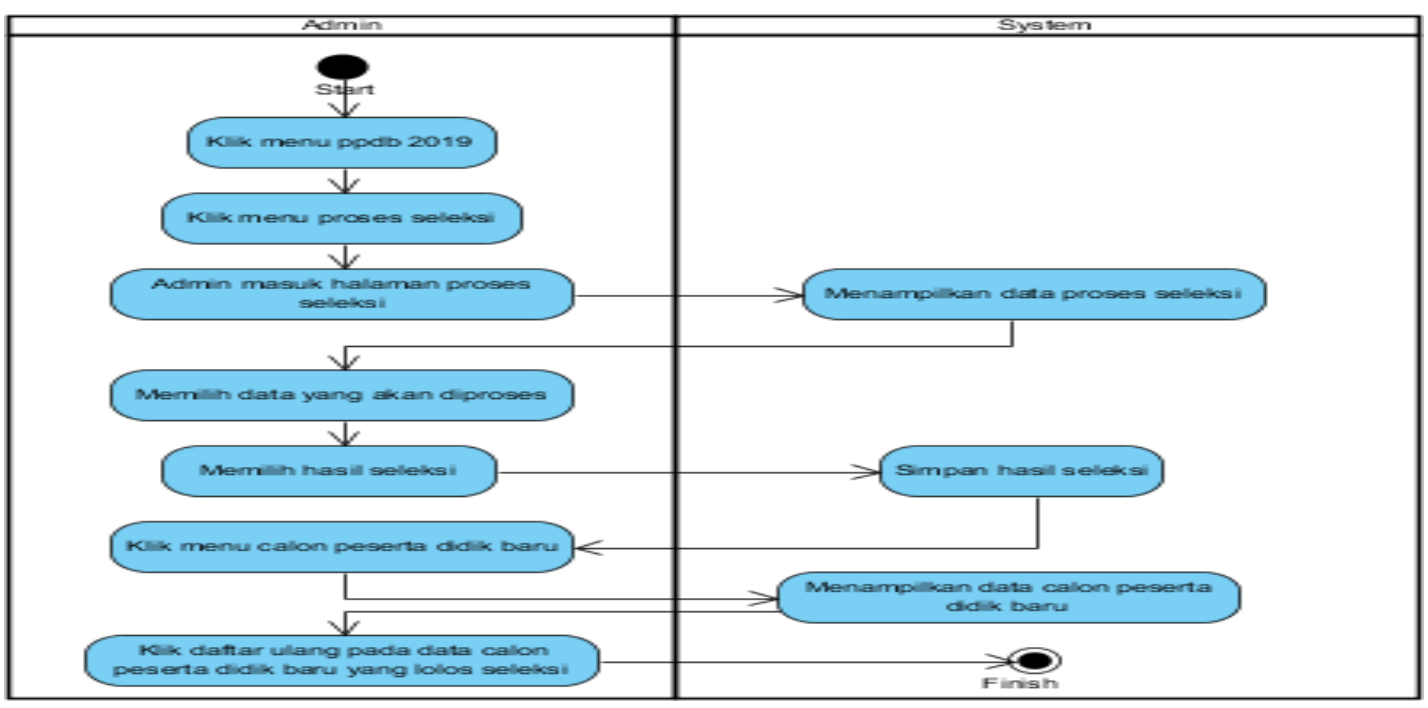

Gambar 6. Activity Diagram Use Case Menambah Data Calon Peserta didik

\subsubsection{Activity Diagram Use Case User}

Activity Diagram berikut menggambarkan proses melihat isi web yang dilakukan oleh user adalah sebagai berikut : 


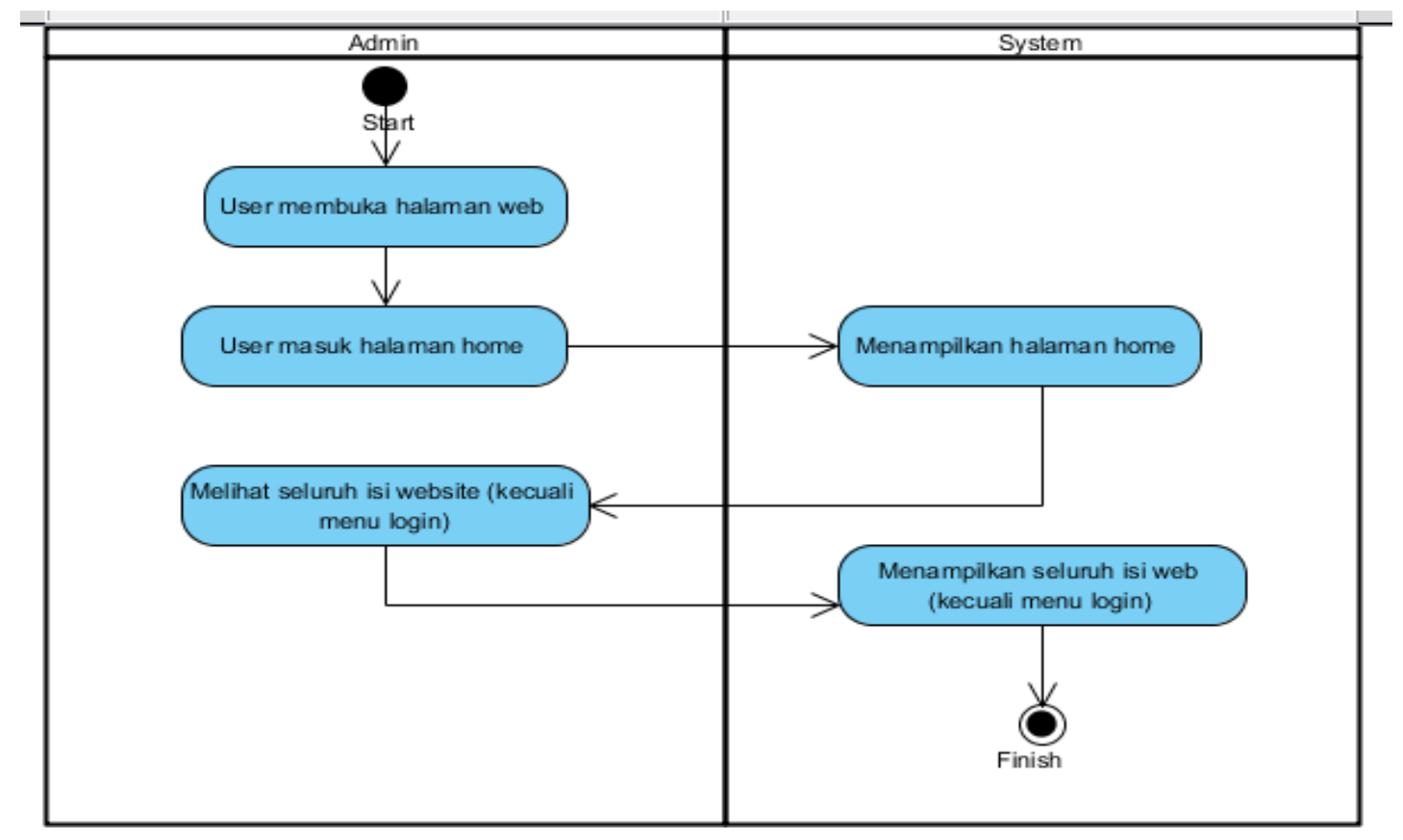

Gambar 7. Activity Diagram Use Case User

\subsubsection{Sequence Diagram Login}

Sequence Diagram adalah suatu diagram yang menggambarkan interaksi antar objek dan mengindikasikan komunikasi diantara objek- objek tersebut. Berikut sequence diagram pada Website Sekolah SMK.S Al Habibatain Bumiayu:

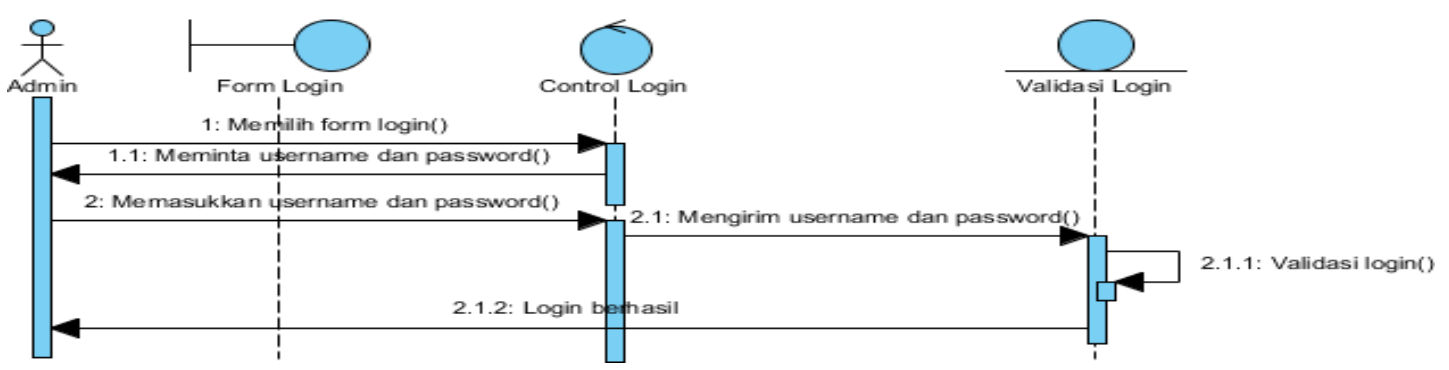

Gambar 8. Sequence Diagram Login 


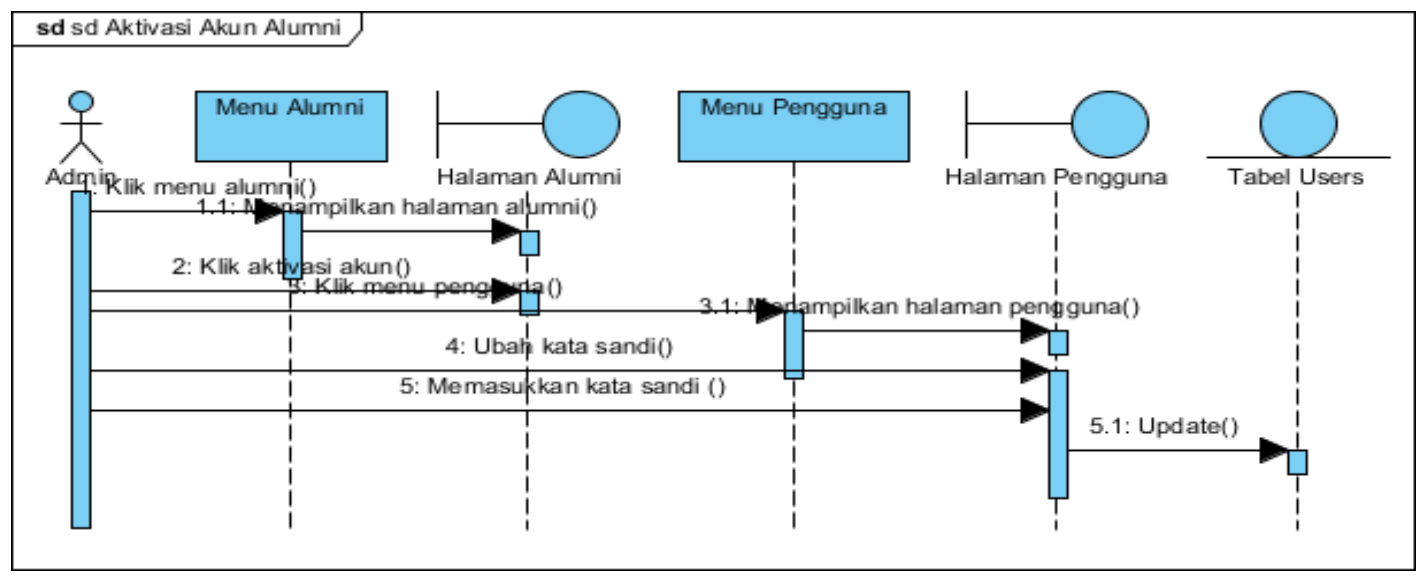

Gambar 9. Sequence Diagram Aktivasi Akun Data Alumni

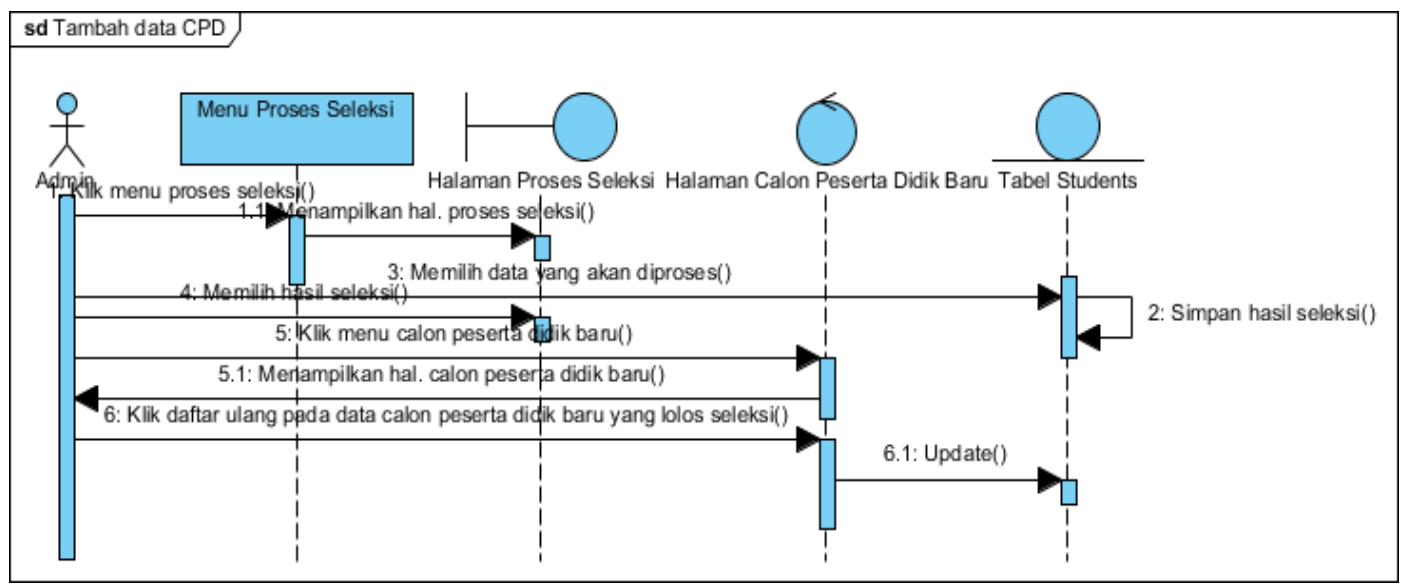

Gambar 10. Sequence Diagram Edit Peserta didik

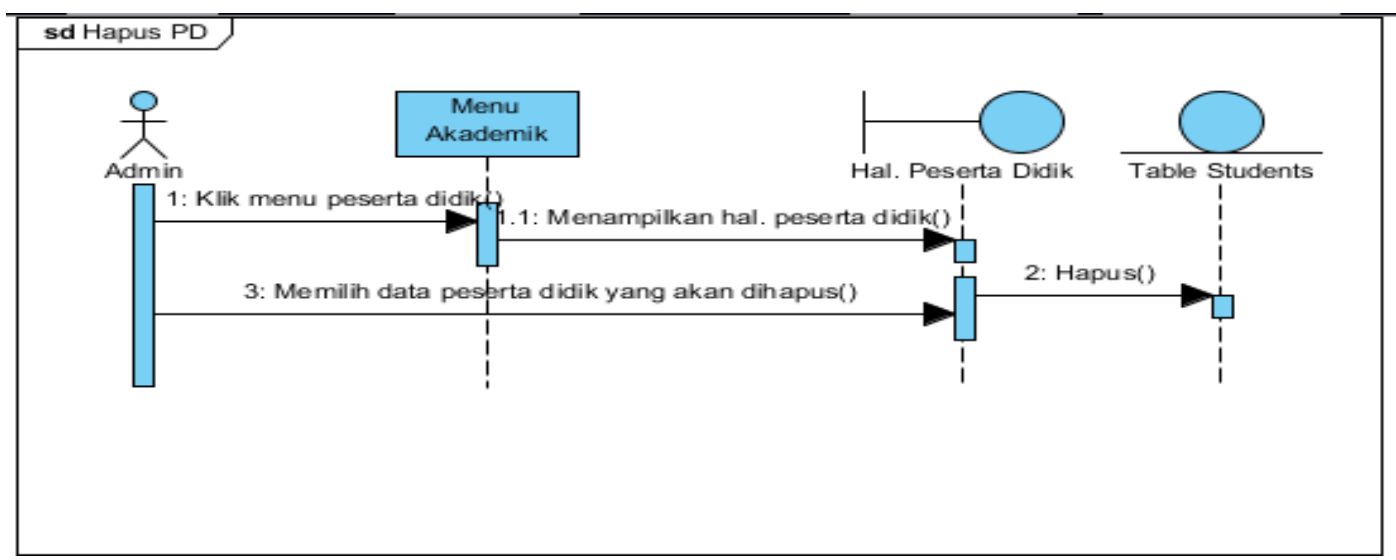

Gambar 11. Sequence Diagram Hapus Peserta didik 


\subsubsection{Kamus Data}

Kamus data adalah suatu daftar data elemen yang terorganisir dengan definisi yang tetap dan sesuai dengan sistem, sehingga pengguna dan analis sistem mempunyai pengertian yang sama tentang input, output dan komponen data store.

\subsubsection{Tabel Tahun Akademik}

Nama Tabel : cademic_years

Primary Key : id

Keterangan : Tabel ini berisikan data tahun akademik

Tabel 1. Tahun Akademik

\begin{tabular}{|c|c|c|c|}
\hline Fileld & Type & $\begin{array}{l}\mathrm{Si} \\
\mathrm{ze}\end{array}$ & Keterangan \\
\hline id & bigint & 20 & $\begin{array}{l}\text { Nomor identitas tahun } \\
\text { akademik }\end{array}$ \\
\hline academic_year & varchar & 9 & Tahun akademik \\
\hline semester & $\begin{array}{l}\quad \text { enum } \\
\text { ('odd','eve } \\
\text { n') }\end{array}$ & & Odd = ganjil, Even = Genap \\
\hline current_semester & $\begin{array}{l}\text { enum } \\
\text { ('true','false } \\
\text { ') }\end{array}$ & & Menunjukkan semester sekarang \\
\hline admission_semester & $\begin{array}{c}\text { enum } \\
\text { ('true','false } \\
\text {,) }\end{array}$ & & \\
\hline created_at & datetime & & Tanggal dibuat \\
\hline updated_at & timestamp & & Waktu diupdate \\
\hline deleted_at & timestamp & & Waktu didelete \\
\hline created_by & bigint & 20 & Nomor identitas si pembuat \\
\hline updated_by & bigint & 20 & $\begin{array}{l}\text { Nomor identitas si } \\
\text { pengupdate }\end{array}$ \\
\hline deleted_by & bigint & 20 & Nomor identitas si penghapus \\
\hline restored_by & bigint & 20 & $\begin{array}{l}\text { Nomor identitas si } \\
\text { perestore }\end{array}$ \\
\hline
\end{tabular}




\subsubsection{Tabel Achievements}

Nama Tabel : achievements

Primary Key : id

Keterangan : Tabel ini berisikan data-data prestasi peserta didik

Tabel 2. Achievements

\begin{tabular}{|l|c|c|l|}
\hline \multicolumn{1}{|c|}{ Field } & Type & Size & Keterangan \\
\hline idUtama & bigint & 20 & \\
\hline student_idIndeks & bigint & 20 & \\
\hline $\begin{array}{l}\text { achievement_ } \\
\text { description }\end{array}$ & varchar & 255 & \\
\hline achievement_type & bigint & 20 & \\
\hline achievement_level & smallint & 6 & \\
\hline achievement_year & year & 4 & \\
\hline $\begin{array}{l}\text { achievement_ } \\
\text { organizer }\end{array}$ & varchar & 255 & \\
\hline created_at & datetime & & \\
\hline updated_at & timestamp & & \\
\hline deleted_at & datetime & & \\
\hline restored_at & datetime & & \\
\hline created_by & bigint & 20 & \\
\hline updated_by & bigint & 20 & \\
\hline deleted_by & bigint & 20 & \\
\hline restored_by & bigint & 20 & \\
\hline is_deleted & $\begin{array}{c}\text { enum('true', } \\
\text { 'false') }\end{array}$ & & \\
\hline
\end{tabular}

\subsubsection{Tabel Admission Phases}

Nama Tabel : admission_phases

Primary Key : id

Keterangan : Tabel ini berisikan data-data gelombang pendaftaran

Tabel 3. Admission Phases

\begin{tabular}{|l|c|c|c|}
\hline \multicolumn{1}{|c|}{ Field } & Type & Size & Keterangan \\
\hline idUtama & bigint & 20 & \\
\hline academic_year_idIndeks & bigint & 20 & Tahun Pelajaran \\
\hline phase_nameIndeks & varchar & 255 & Gelombang Pendaftaran \\
\hline phase_start_date & date & & Tanggal Mulai \\
\hline phase_end_date & date & & Tanggal Selesai \\
\hline created_at & datetime & & $\begin{array}{c}\text { Tanggal Waktu } \\
\text { Dibuat }\end{array}$ \\
\hline updated_at & timestamp & & Waktu Diupdate \\
\hline
\end{tabular}




\begin{tabular}{|l|c|c|c|}
\hline deleted_at & datetime & & Tanggal Waktu Dihapus \\
\hline restored_at & datetime & & $\begin{array}{c}\text { Tanggal Waktu } \\
\text { Direstore }\end{array}$ \\
\hline created_by & bigint & 20 & Nomor Pembuat \\
\hline updated_by & bigint & 20 & Nomor Pengupdate \\
\hline deleted_by & bigint & 20 & Nomor Pendelete \\
\hline restored_by & bigint & 20 & Nomor Perestore \\
\hline is_deleted & $\begin{array}{c}\text { enum } \\
\text { ('true','false') }\end{array}$ & & Status Terhapus \\
\hline
\end{tabular}

\subsubsection{Tabel Albums}

Nama Tabel : Albums

Primary Key : id

Keterangan : Tabel ini berisikan album gambar

Tabel 4. Albums

\begin{tabular}{|l|c|c|l|}
\hline \multicolumn{1}{|c|}{ Field } & Type & Size & \multicolumn{1}{|c|}{ Keterangan } \\
\hline idUtama & bigint & 20 & \\
\hline album_titleIndeks & varchar & 255 & Title Album \\
\hline album_description & varchar & 255 & Deskripsi Album \\
\hline album_slug & varchar & 255 & \\
\hline album_cover & varchar & 100 & Cover Album \\
\hline created_at & datetime & & Tanggal Waktu Dibuat \\
\hline updated_at & timestamp & & Waktu Diupdate \\
\hline deleted_at & datetime & & Tanggal Waktu Dihapus \\
\hline restored_at & datetime & & Tanggal Waktu Direstore \\
\hline created_by & bigint & 20 & Nomor Pembuat \\
\hline
\end{tabular}

\section{Hasil dan Pembahasan}

Hasil dan pembahasan memuat hasil dari analisi desain sistem perancangan sistem berupa tampilan antarmuka sistem informasi akademik SMK-S Habibatain Bumiayu dengan user friendly sehingga memudahkan pengguna dalam menggunakan aplikasi ini. 


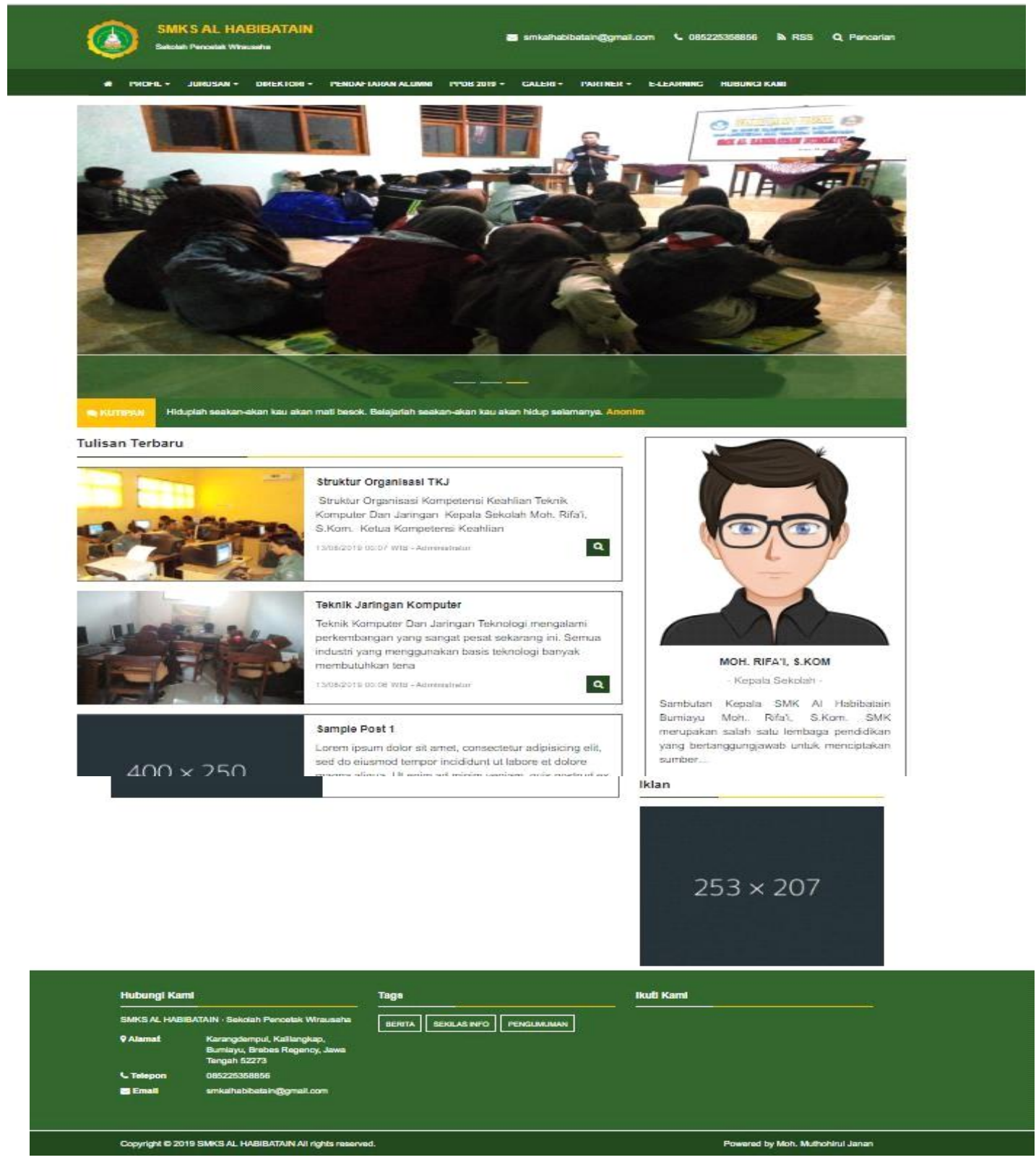

Gambar 12. Halaman Antarmuka 


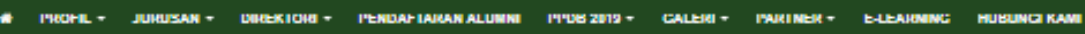

Pendaftaran Alumni

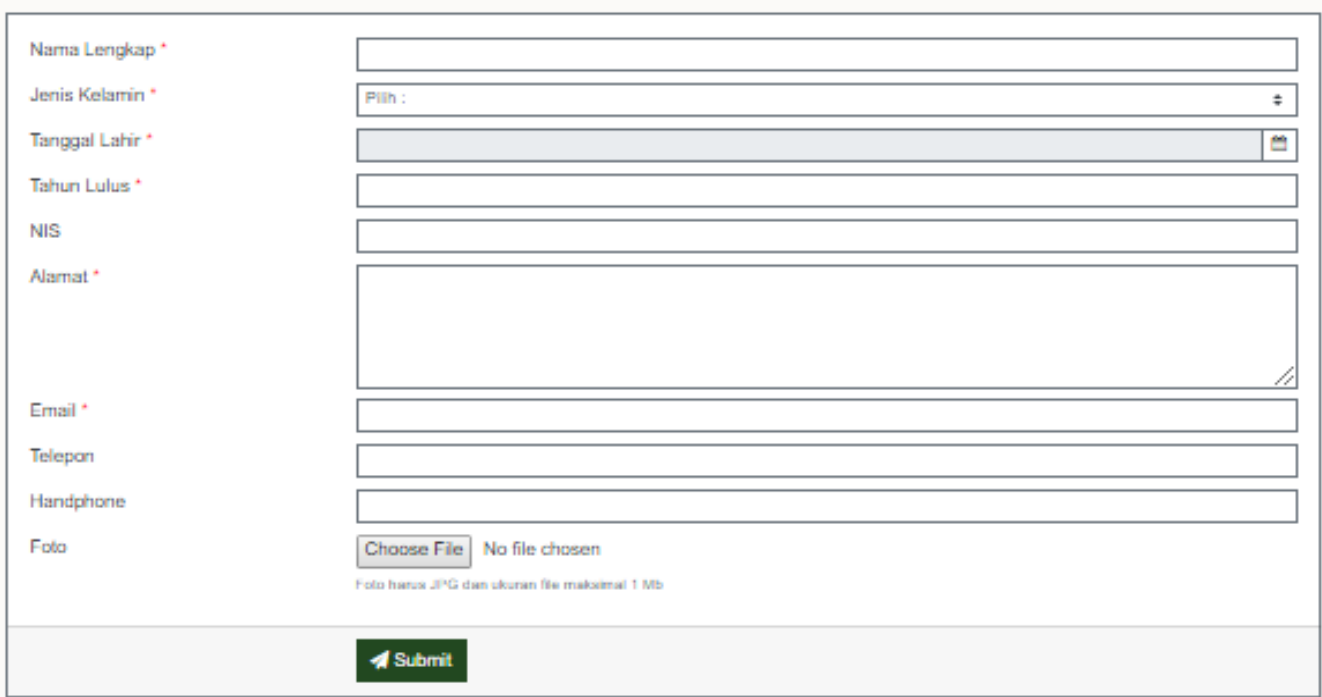

Gambar 13. Antarmuka Halaman Pendaftaran Alumni

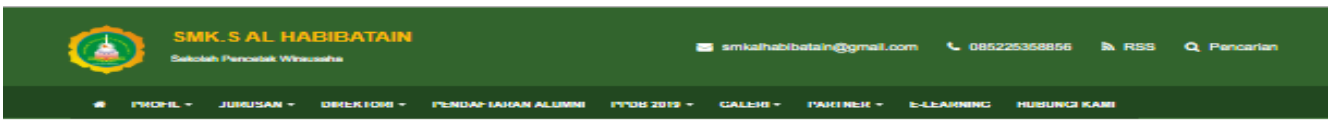

Formulir Penerimaan Peserta Didik Baru Tahun 2019

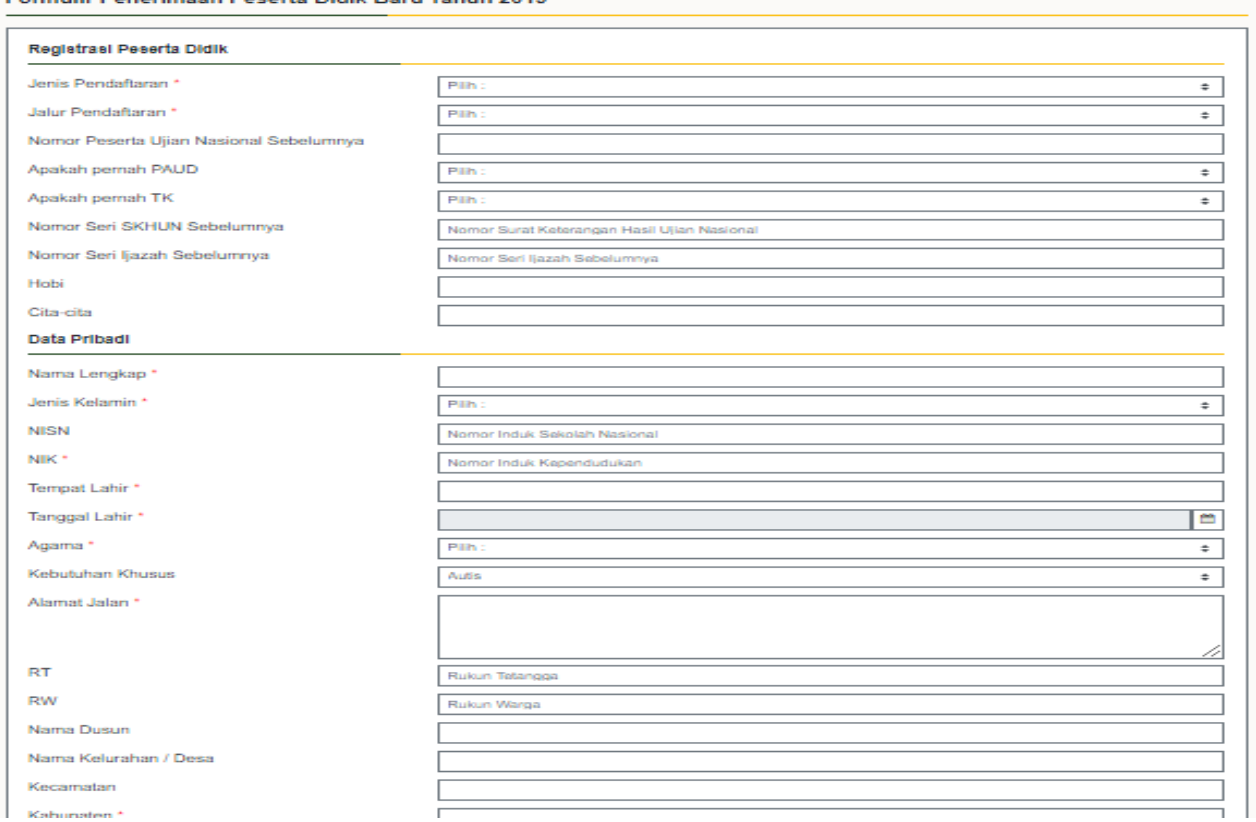

Gambar 14. Antarmuka Halaman PPDB 


\section{Pengujian Sistem}

Pengujian sistem pada website sekolah SMK.S Al Habibatain Bumiayu ini adalah dengan menggunakan pengujian Blackbox. Hasil pengujian Blackbox dapat dilihat pada tabel di bawah ini.

Tabel 5. Hasil Pengujian Blackbox

\begin{tabular}{|c|c|c|c|}
\hline No & Skenario Penguji & Hasil Yang Diharapkan & Kesimpulan \\
\hline 1. & $\begin{array}{l}\text { Mengosongkan username \& } \\
\text { password lalu klik tombol } \\
\text { Sign in. }\end{array}$ & $\begin{array}{l}\text { Sistem akan menolak } \\
\text { akses login dan menampilkan } \\
\text { pesan login gagal. }\end{array}$ & Valid \\
\hline 2. & $\begin{array}{l}\text { Memasukkan username \& } \\
\text { password yang salah lalu klik } \\
\text { tombol Sign in. }\end{array}$ & $\begin{array}{l}\text { Sistem akan } \\
\text { memverifikasi akun dan akan } \\
\text { menolak login jika username } \\
\text { dan password yang dimasukkan } \\
\text { salah serta menampilkan } \\
\text { pesan login gagal. }\end{array}$ & Valid \\
\hline 3. & $\begin{array}{l}\text { Memasukkan username \& } \\
\text { password yang benar lalu klik } \\
\text { tombol Sign in. }\end{array}$ & $\begin{array}{lrr}\text { Sistem } & \text { akan } & \\
\text { memverifikasi } & \text { akun } & \text { dan } \\
\text { menampilkan } & \text { pesan } & \text { login } \\
\text { sukses.. } & & \end{array}$ & Valid \\
\hline 4. & $\begin{array}{l}\text { Menambahkan data Guru dan } \\
\begin{array}{l}\text { Tenaga } \\
\text { Kependidikan lalu klik } \\
\text { tombol save. }\end{array} \\
\end{array}$ & $\begin{array}{lc}\text { Sistem } & \text { akan } \\
\text { menyimpan } & \text { dan menampikan } \\
\text { data yang } & \text { sudah } \\
\text { ditambahkan. } & \end{array}$ & Valid \\
\hline
\end{tabular}




\section{Kesimpulan}

Hasil dari penelitian ini yaitu menerapkan metode waterfall dalam membangun sistem informasi akademik berbasis website yang lebih tersistematis dan terencana dengan baik sehingga diperoleh aplikasi yang userfriendly.

\section{Daftar Pustaka}

[1] Sugiri dan H. Saputro, PENGELOLAAN DATABASE MySQL dengan PhpMyAdmin, Yogyakarta: Graha Ilmu, 2008.

[2] A. Hariyanto, Membuat Aplikasi Computer Based Text dengan PHP, MySQLi dam Bootsrap, Yogyakarta: CV. LOKOMEDIA, 2017.

[3] A. Kadir, Mudah Menjadi Programmer PHP, Yogyakarta: CV ANDI OFFSET, 2009.

[4] W. F. Kusuma, "Jurnal Teknik Informatika," PENGEMBANGAN HALAMAN WEB MENGGUNAKAN XML DALAM PERKEMBANGAN WEB 2.O, 2015.

[5] D. S. Manne, S. Yelisetti, M. Kakarla dan D. S. Fatima, Mining VRSEC Student Learning Behaviour In Moodle System Using Datamining Techniques, p. 7, 2014.

[6] D. Puspitasari, "Jurnal Pilar Nusa Mandiri," SISTEM INFORMASI PERPUSTAKAAN SEKOLAH BERBASIS WEB, vol. XII, p. 14, 2016.

[7] A. Hendini, "Jurnal Khatulistiwa Informatika," PERMODELAN UML SISTEM INFORMASI MONITORING PENJUALAN STOK BARANG (STUDI KASUS:DISTRO ZHEZHA PONTIANAK), 2016.

[8] Hardiyan dan Mahpud, "Jurnal Techno Nusa Mandiri," PENERAPAN METODE WATERFALL PADA PROGRAM APLIKASI PENGOLAHAN NILAI ONLINE PADA SMP ISLAM ABAABIL TANGERANG, pp. 43-47, 2017.

[9] B. Sidik, "Pemrograman Web dengan PHP : Edisi Revisi Kedua," Pemrograman, 2014.

[10] N. Utami, "Sistem informasi inventori barang pt. tissan nugraha globalindo berbasis web publikasi ilmiah," Sistem Informasi Inventori Barang Pt. Tissan Nugraha Globalindo Berbasis Web, 2018. 